\title{
Flexible Wage Contracts, Temporary Jobs, and Firm Performance: Evidence From Italian Firms
}

\author{
MICHELE BATTISTI and GIOVANNA VALLANTI*
}

This study focuses on the effects of decentralized wage schemes and temporary forms of employment on firm performance. The effect of monetary incentives on workers' effort and firm performance is a central topic in economics. According to the principal-agent paradigm, firms (the principal) have to link employees' remuneration schemes to any verifiable indicator of performance to avoid opportunistic behavior. The empirical evidence shows that financial incentives have the potential to exert strong effects on indicators of firm performance, such as productivity and worker absenteeism, although the degree of effectiveness of such schemes varies significantly according to the institutional/economic context in which firms operate. From both a theoretical and empirical point of view, the prediction on the effects of temporary types of employment on effort and productivity is less neat. In light of these considerations, this study uses a sample of Italian firms to provide further empirical evidence on whether and to what extent performance-related pay schemes and contract flexibility affect workers' effort (in terms of absenteeism) and, in turn, firm productivity. These effects are analyzed for different types of workers (white collar vs. blue collar), working in workplaces characterized by a different degree of uncertainty and risk and in firms operating in different economic and institutional settings. Our results show that wage flexibility has a significant effect on effort and then on firm's productivity and that white-collar workers are more responsive to monetary incentives than blue-collar workers. Moreover, the presence of a large share of temporary contracts, implying a lower dismissal probability for permanent workers and a deterioration of the working environment, appears to reduce workers' motivation and effort.

\section{Introduction}

THE LAST TWO DECADES HAVE WITNESSED A SIGNIFICANT INCREASE IN THE LABOR MARKET flexibility in all European countries. Rigidities in the labor market are

\footnotetext{
* The authors' affiliations are, respectively, University of Palermo, LUISS Guido Carli and RCEA Palermo, Italy. Email: mbattisti@luiss.it; Department of Economics and Finance and LLEE, University LUISS “Guido Carli,” Rome, Italy. Email: gvallanti@luiss.it. We wish to thank Massimo Egidi, Francesca Mazzolari, and all the participants of the IAB workshop Labour Market Flexibility: Boon or Bane? -Nurmberg, 18-19 March.

Industrial Relations, Vol. 52, No. 3 (July 2013). (C) 2013 Regents of the University of California Published by Wiley Periodicals, Inc., 350 Main Street, Malden, MA 02148, USA, and 9600 Garsington Road, Oxford, OX4 2DQ, UK.
} 


\section{8 / Michele Battisti and Giovanna Vallanti}

considered by the most debated strand of macroeconomic literature among the key causes of the poor performance of the labor market both in terms of participation and employment (among others Blanchard and Wolfers 2000; Burgess, Lane, and Stevens 2000; Siebert 1997). In this study, we are interested in an empirical assessment of the effects of flexibility on firm productivity through workers' performance, which depends on a number of components such as effort (one of its dimensions being absenteeism), worker cooperation, and so on. In particular, we will focus on two forms of flexibility commonly identified by the literature: external (numerical) flexibility and wage (financial) flexibility. ${ }^{1}$ The former is related to the capacity of the firm to adjust its workforce to changes in the economic conditions and depends on the strictness of employment protection legislation and the availability of temporary forms of employment, while the latter concerns the responsiveness of wages to external shocks and changes in internal productivity and largely depends on the features of the wage setting institutions.

Temporary employment has grown in a number of OECD countries during the past two decades raising concerns that temporary jobs may be crowding out more stable forms of employment, becoming an additional source of insecurity for workers. From a theoretical and empirical point of view, the effects of temporary forms of employment on productivity are ambiguous and depend mainly on the reasons why employers use them. For instance, Boeri and Garibaldi (2007) find a positive temporary effect on employment and a permanent negative effect on productivity, while other authors (see for example Ichino and Riphahn 2005) find a positive impact when temporary jobs have a high probability to be transformed into permanent ones after the probation period. Generally speaking, the use of temporary workers as buffer stocks increases job instability and uncertainty inside the firm, reduces investment in training, lowers workplace cooperation and workers' motivations, and harms long-run growth prospects (Blanchard and Landier 2002). On the contrary, temporary contracts used as screening devices generate better growth prospects due to better learning about the quality of the match and lower incentive to shirking for temporary workers. This may translate into better job matches and, therefore, more stable employer-employee relationships in the long run (Portugal and Varejao 2009).

Considering the second dimension of flexibility, there is a large theoretical and empirical literature on the effects of wage incentive schemes on effort and productivity. The efficiency wage theory in the eliciting effort version (Shapiro and Stiglitz 1984; Solow 1979) shows that firms pay higher salary to motivate

\footnotetext{
${ }^{1}$ For a detailed classification of labor market flexibility see Beatson (1995).
} 
workers to work harder. A similar reason, else if in a dynamic setting inside the careers' profiles is the basis to design right schemes of incentives under tournaments (Lazear and Rosen 1981). It means that in the face of asymmetric information, firms should tie the remuneration of employees to any verifiable (individual or collective) signal of performance. Based on such a theoretical prediction, a number of studies in recent years have shown that, when implemented wisely, financial incentives have the potential to exert strong effects on indicators of firm performance, such as productivity (Damiani and Ricci 2008; Fuss 2009; Gielen, Kerkhofs, and Ours 2010; Lazear 2000), labor demand for flexible workers (Benito and Hernando 2008), and workers' effort (Brown, Fakhfakh, and Sessions 1999; Gomez-Mejia and Balkin 1989; Wilson and Peel 1991). By exploiting another dimension of wage flexibility Guiso, Pistaferri, and Schivardi (2005) find that sensitivity of workers' wages to permanent shocks is negatively correlated with the workers' risk aversion and the overall variability of firm performance.

In Italy, the period of labor market reforms aimed at reducing worker protection and increasing decentralized wage determination started at the beginning of the 1990 s with the tripartite agreements of 1993 (signed by the national trade unions, government, and industrial associations), which marked the end of the automatic wage indexation system (the so-called scala mobile). ${ }^{2}$ Moreover, the 1993 agreement introduced a two stage bargaining system consisting of national-level bargaining (by economic sector) and local-level agreements. The main objective of the national/sector-level bargaining was to maintain the purchasing power of wages and to determine the basic wage guarantees (minimi tabellari), which represent a floor to wage adjustments. Local bargaining (either at the regional or firm level) had to allow possible rent sharing through performance-related pay schemes rather than fixed (usually irreversible) premiums. Institutional reforms aimed at deregulating the Italian labor market through the introduction of various forms of temporary and atypical contracts have been gradually introduced since the mid-1990s. The two principal reforms in this direction have been the Treu reform in 1997 and Biagi reform in $2003,{ }^{3}$ which (de)regulated and extended the adoption of fixed-term contracts, allowed the use of temporary agency workers, and introduced new "atypical" contractual arrangements.

To assess how and in what direction reforms have impacted the Italian regulatory framework and how Italy ranks in comparison with other industrialized

\footnotetext{
${ }^{2}$ In light of the inverted u-shape relationship found in Calmfors and Driffill (1988) and Tarantelli (1986) this means a shift on the left tail of the curve.

${ }^{3}$ Elia (2010) used the 2003 reform as an instrument to test how the wage gap for permanent-temporary workers changed after that break, finding a positive effect on this gap stronger for skilled workers.
} 


\section{0 / Michele Battisti and Giovanna Vallanti}

countries, we can look at a standard de jure labor market flexibility indicator, the Employment Protection Index (EPL) constructed by the OECD. According to the EPL indicators, in 2008 Italy ranks broadly mid-field in OECD comparison (twenty-fifth out of forty countries) with the EPL indicators being 1.89 against an OECD average of 1.94. In 1990, Italy ranked fourth out of twenty-six countries in the same decreasing order of protection. We should stress that, in Italy, as in many other European countries in the 1990s, the increase in flexibility was mainly obtained through the liberalization of the use of temporary forms of employment while leaving unchanged the protection of permanent incumbent workers. Concerning wage flexibility, Clar, Dreger, and Rams (2007) rank Italy twelfth out of eighteen OECD countries in a meta-analysis, thus confirming the previous results obtained by Heylen (1993). This seems to indicate that these reforms have changed numerical flexibility much more than wage flexibility.

Using a sample of Italian firms, the aim of this study is to empirically assess whether and to what extent decentralized wage schemes on one hand and temporary forms of employment on the other, affect worker absenteeism and more generally firms' productivity. We want also to disentangle the specific contribution of wage and employment flexibility to firm productivity. Finally, we use white and blue collar workers as different labor inputs in the production function to see whether they are affected differently by flexibility practices. The remainder of the work is structured it follows. In the next section, we explain our empirical strategy and briefly describe the methodology we use. Next, we describe the data sets we use and the characteristics of the sample. In the Results section, we present and discuss the results of the empirical analysis, followed by conclusive considerations.

\section{Empirical Strategy and Measurement Issues}

To assess the impact of wage and numerical flexibility on productivity, our empirical model takes into account the simultaneous interactions between workers' effort and firms' performance on the one hand and workers' effort and its determinants on the other. One important issue is how to define and measure workers' effort. Despite there is consensus on the fact that the commitment and effectiveness with which workers fulfill their assigned tasks matters for labor productivity, neither the theoretical nor the empirical literature provide a unique, widely accepted definition of this concept.

The empirical literature has operationalized the idea of effort in a number of different ways, which may be classified in two broad categories. The first category includes studies which use observable and "objective" indicators of effort (or negative effort) such as absenteeism (Arai and Thoursie 2005; Barmby, 
Orme, and Treble 1991; Bradley, Green, and Leeves 2007; Engellandt and Riphahn 2005; Ichino and Riphahn 2005; Winckelmann 1999) or disciplinary dismissals (Cappelli and Chauvin 1991). Other studies, which are based on information collected from surveys of employees consider self-reported (subjective) measures of effort/motivation as indicators of individual commitment to work.

Our approach is twofold. First, we use an observable component of effort (negative absenteeism) and estimate a model in which workers' absenteeism and firm productivity are both observable and endogenous. Absenteeism can be considered a measure of workers' shirking for a number of reasons. Given asymmetric information on workers' health conditions, workers may try to reduce the amount of work by deciding to report sick even when they are not. $^{4}$ Moreover, since in Italy absence due to illness cannot be compensated with extra hours above the working hours, which are set by collective agreements, and employees are fully insured against earning losses due to illness, absenteeism may be considered a good empirical proxy for employees' shirking behavior. Although effort has additional dimensions other than absenteeism, such as workers' cooperation and work intensity, the latter, though correlated with absenteeism, are generally not observable.

Secondly, as absenteeism captures one dimension of effort, we carry out additional checks to assess the (direct) effects of our numerical and wage flexibility on firms' performance. Following Black and Lynch's (2001) two-step procedure, we estimate a firm-specific time-invariant component from the residuals of a production function over the longest time span for which we have data availability. We then regress this component on the flexibility indicators. This firm-specific time-invariant component of the production function is something broader than effort as it may be identified as an indicator for technical efficiency, which includes effort as well as other characteristics such as managerial quality, human capital training, cooperation between workers, informational issues, and others. This second specification allows us to assess whether and to what extent flexibility may have an impact on firm productivity not only through absenteeism but also through other unobservable components of technical efficiency. We further check the robustness of our results using the structural equation modeling (SEM) technique, which allows us to capture the relationship between the unobserved (latent) variable effort and firms' productivity.

\footnotetext{
${ }^{4}$ Among others, see Brown and Sessions (1996) for a review of the literature and Markussen et al. (2011) for extensive evidence on the relevance of moral hazard issues in determining sickness absence levels.
} 


\section{2 / Michele Battisti and Giovanna Vallanti}

The basic model. The basic framework is a standard Cobb-Douglas production function for a representative firm with only two inputs: effective labor $(E)$ and capital $(K)$

$$
\begin{gathered}
Y_{i}=A_{i} K_{i}^{\alpha} E_{i}^{\beta} \exp ^{u_{i}} \\
E_{i}=e_{i} \hat{L}_{i} \\
e_{i}=f\left(Z_{i}\right),
\end{gathered}
$$

where $E$ is a broad concept of the labor factor including effort (equation 2). In particular, $e_{i}$ is the average effort of the labor force in firm $i$ and $\hat{L}_{i}$ is the number of workers employed expressed in terms of full-time equivalent units and adjusted for quality (human capital), type of contracts (temporary vs. permanent), and qualification of employees (blue collar vs. white collar). In turn, the average amount of effort in firm $i$ is influenced by a number of variables in the vector $\mathbf{Z}_{i}$, which contains:

1. Wage structure indicators, which include a performance-related pay element (as a share of total remuneration), ${ }^{5}$ other production premia and bonuses, super minimum differentials, and seniority differentials. ${ }^{6}$

2. Numerical (external) flexibility indicators, which include the share of temporary contracts (fixed-term contracts, traineeship contracts, and other "atypical" contracts ${ }^{7}$ ), conversion rates (from temporary to permanent jobs), turnover rate, hiring policies (temporary vs. permanent), and displacement risk. We also include an indicator of the degree of employment protection related to firm dimension and a dummy for the strictness of employment protection legislation, which assumes value 1 for firms with more than fifteen employees and zero otherwise. ${ }^{8}$

\footnotetext{
5 This component of the wage is based on previous year performance results. The performance results are decided without formal negotiations with the trade unions and not on permanent basis.

${ }^{6}$ Super minimum are company-level wage increments added to the contractual minimum on a permanent basis with either a firm-level or a worker-level component. Super minimum and seniority differentials are relative to firms operating in the same sector of activity.

7 Atypical contracts include external collaborations and agency contracts.

${ }^{8}$ According to the Art. 18 of the "Statuto dei Lavoratori" (Law 300), firms with more than fifteen employees had to reinstate workers and pay their foregone wages in case of unfair dismissals. On the other hand, firms with fewer than sixteen employees have to pay severance payments without any reinstatement. This means that the cost of unfair dismissals for firms with fewer than fifteen employees is lower relative to the cost for firms with more than fifteen employees.
} 
3. Workers' outside opportunities such as the local unemployment rate (that is a measure of the degree of the economic activity in the local labor market) and indicators of the characteristics of the local production area (whether the firm is located in an industrial district or in a metropolitan area).

4. Labor force and firm characteristics such as human capital endowment and gender composition, firm size, workers' contractual arrangements, and workers' qualification (white collar and blue collar).

Effort $e_{i}$ is proxied by an indicator of (negative) absenteeism, which is measured at firm level as the ratio between the actual worked hours and the total contractual working hours. ${ }^{9}$

We allow labor input heterogeneity by differentiating workers by multiple characteristics. We distinguish between temporary and permanent workers, skilled and unskilled workers, and white and blue collar workers.

The empirical specification is the following: ${ }^{10}$

$$
\begin{gathered}
\ln Y_{i}=\alpha \ln K_{i}+\beta \ln (e L)_{i}+\varphi_{T}\left(\frac{L_{T}}{L}\right)_{i}+\varphi_{H}\left(\frac{L_{H}}{L}\right)_{i}+\varphi_{W}\left(\frac{L_{W}}{L}\right)_{i}+u_{i} \\
\ln e_{i}=\gamma^{\prime} Z_{i}+\varepsilon_{i} .
\end{gathered}
$$

In equation (4), $\phi_{T} / \beta$ represents the productivity premium of a temporary worker relative to a permanent worker, $\phi_{H} / \beta$ represents the productivity premium of a high-schooled worker relative to a low-schooled worker, and $\phi_{W} / \beta$ represents the productivity premium of a white-collar relative to a blue-collar worker (Konings and Vanormelingen 2010). Unfortunately, we do not observe the number of high-schooled and low-schooled workers, nor the number of temporary and permanent workers for each employee type. This forces us to make some simplifying assumptions similar to other studies that divide the labor force across several dimensions (Konings and Vanormelingen 2010; Van Biesebroeck 2007). First, we assume that the relative differences in marginal productivity between two workers that differ by one characteristic are the same, irrespective of their other characteristics. Second, we restrict the proportion of one type of worker to be constant across other groups defined by the other characteristics.

\footnotetext{
${ }^{9}$ The average hours of absence at firm level are calculated as the hours lost due to sickness (3.5 percent of working time), and other paid absences, which include medical visits, union activity, and parental leaves apart from compulsory maternity (1.5 percent of working time).

${ }^{10}$ See Appendix 1 in Konings and Vanormelingen (2010) for a formal derivation of the empirical specification of equation (1) where workers can be differentiated by multiple characteristics.
} 


\section{4 / Michele Battisti and Giovanna Vallanti}

The model with heterogeneous workers. We relax the assumption that blue-collar and white-collar workers are perfect substitutes. Similarly to equation 1 , we divide the workforce by their human capital characteristics and type of contract and allow blue-collar and white-collar workers to be imperfectly substitutable in the production process. We then include effective labor for blue-collar and white-collar workers separately in the production function, obtaining the following specification: ${ }^{11}$

$$
\begin{gathered}
Y_{i}=A_{i} K_{i}^{\alpha} E_{W, i}^{\beta_{W}} E_{B, i}^{\beta_{B}} \exp ^{u_{i}} \\
E_{W, i}=e_{W, i} \hat{L}_{W, i} \\
E_{B, i}=e_{B, i} \hat{L}_{B, i} \\
e_{W, i}=f\left(Z_{W, i}\right) \\
e_{B, i}=f\left(Z_{B, i}\right),
\end{gathered}
$$

where $e_{B, i}$ and $e_{W, i}$ are the average levels of effort of blue-collar and whitecollar workers, respectively, in firm $i$. As before, the average effort is influenced by a number of variables in the vectors $\mathbf{Z}_{B i}$ and $\mathbf{Z}_{W i}$, which may be specific to workers' qualification.

The corresponding empirical specification for the system of equations is the following:

$$
\begin{gathered}
\ln Y_{i}=\alpha \ln K_{i}+\beta_{W} \ln \left(e_{W} L_{W}\right)_{i}+\beta_{B} \ln \left(e_{B} L_{B}\right)_{i}+\phi_{T}\left(\frac{L_{T}}{L}\right)_{i}+\phi_{H}\left(\frac{L_{H}}{L}\right)_{i}+u \\
\ln e_{W i}=\gamma_{W}^{\prime} Z_{W i}+\varepsilon_{W i} \\
\ln e_{B i}=\gamma^{\prime} Z_{B i}+\varepsilon_{B i},
\end{gathered}
$$

where the effort equations for white-collar and blue-collar workers are estimated separately.

These two systems of equations are estimated through a three-stage leastsquares technique, given the simultaneity of the work variables in the production and in the effort functions.

\footnotetext{
${ }^{11}$ Although we could also observe the number of managers in a firm, including them separately in the production function would have implied to exclude too many observations because only a small percentage of firms report a positive number of managers. We count the number of managers as white-collar workers instead.
} 


\section{Data Description}

The empirical analysis is based on firm-level data sourced from the annual labor market survey carried out by the Italian Manufacturing and Service Industries Association (Confindustria). The aim of the survey is to collect information on the state of employment in the Italian productive sectors (with a focus on industry sectors), with particular reference to the structural economic-normative aspects normally overlooked by official surveys. On average around 4400 firms employing more than 732,000 workers are surveyed every year. The Confindustria labor market survey is administered at establishment/ firm level by the territorial associations of Confindustria, which are in charge of the distribution and collection of the questionnaires to/from their affiliated firms. The entire database is then processed at a centralized level where the data are subject to extensive quality checks.

The Confindustria survey is a unique source of information on firms' wage strategy (wage structure for different type of workers) and numerical flexibility practices (both in terms of stocks and flows). Moreover, it provides detailed information on the human capital characteristics of the workforce employed in the firms and working time.

The questionnaire consists of three main sections. The first section asks questions on the employment composition of the firm (by sex, type of contract, education and qualification) and job flows (hires by type of contract, number of fixed-term contracts converted to permanent, separation by reason). The second part of the questionnaire asks questions on working time (including overtime and hours of absence by reason) by qualification (manager, white-collar and blue-collar workers). Finally, the third part of the questionnaire contains detailed information on the wage structure by qualification, including the variable pay component disentangled in performance premia (generally based on firm performance) and other individual premia and bonuses (generally related to individual and team performance).

Although the survey is conducted annually, the information on the wage structure and absenteeism (our key variables of interest) is only available for the years 2008 and 2009. Thus, the final sample consists of 2098 firms $^{12}$ over the years 2008 and 2009, with 2009 accounting for the 75 percent of the observations. Although the survey has not been created with a longitudinal design, 17 percent of the firms are surveyed in both years. ${ }^{13}$

\footnotetext{
${ }^{12}$ We exclude from the original sample firms for which detailed information on hours of absence and on wage bill components is not available.

${ }^{13}$ We take into account this features of the sample in several ways in the estimation.
} 


\section{6 / Michele Battisti and Giovanna Vallanti}

We match the data from the Confindustria survey with balance sheets data provided by the AIDA (Analisi Informatizzata delle Aziende Italiane) database $^{14}$ and with information on the conditions and characteristics of local labor markets ${ }^{15}$ provided by the Italian National Institute of Statistics (ISTAT).

Tables 1 and 2 show some descriptive statistics and the sample coverage for the main set of variables we employ in our empirical analysis.

In Table 1, we compare our data with the administrative database on Italian firms and business (ASIA) collected by the Italian National Institute of Statistics. The table shows that, once we exclude microfirms from the comparison, small-medium firms are well represented with a coverage of 72 percent of the sample, although large firms in the manufacturing sector remain slightly overrepresented. ${ }^{16}$ The same comparison shows a good territorial coverage of our data, with the firms located in the Center-South accounting for around 21 percent of the sample (30 percent in the ISTAT database). ${ }^{17}$

Table 2 shows the breakdown of the wage bill into its various components. The industry-wide component accounts for 81 percent of the wage bill, which means that about 20 percent of wage is determined at firm level (column 5 in Table 2). Half of the firm-specific component is the result of local bargaining (super minimum) and the rest is a variable premium (generally based on firms' performance) and other bonuses (set at individual basis). These figures show that there is significant scope for firms to determine the remunerations of their employees above the level set at industry-level bargaining.

\footnotetext{
${ }^{14}$ The AIDA database provides information on firm value added and fixed asset for 2008 and 2009. Moreover, we use data from AIDA (value added, fixed asset, and number of employees) for a longer period of time (from 2000 to 2009) in the estimation of the production function in the first step of the Black and Lynch (2001) procedure.

15 Italy's Local Labour Systems (Sistemi Locali del Lavoro) are defined as self-contained labor markets with respect to daily commuting trips. The Italian territory is partitioned into 686 local labor systems using the Population Census of 2001. The ISTAT (Istituto nazionale di statistica; Italian Statistical Institute) database on Local Labour Systems (SLLs) provides information on the unemployment rate in each SLL and the characteristics of productive areas (namely the presence of an industrial districts and/or of a metropolitan area).

16 According to ASIA (2008), in Italy microfirms (with fewer than fifteen employees) account for almost 95 percent of the productive sectors. Nevertheless, they employ less then 50 percent of the total workforce, while workers employed in large firms (larger than 250 employees) represent more than 20 percent of the total workforce.

${ }^{17}$ Our sample characteristics and coverage is in line with that employed in Guiso, Pistaferri, and Schivardi (2005) in a related analysis, constructed using data from administrative sources (INPS [Istituto Nazionale della Previdenza Sociale; Social Security Italian Institute] and Centrale dei Bilanci). Although the two databases are obtained from two different data sources, they are rather similar in terms of the average number of employees, industry, and geographical coverage. Moreover, the two databases are similar in terms of labor force characteristics (women share, white- and blue-collar shares) and wage structure.
} 
TABLE 1

Descriptive Statistics

Confindustria database (2008-2009) (a) Firm characteristics

Value added

Capital stock

Number of employees

North

Center

South

Industry

Services

Small $(<50)$

Medium (50-250)

Large $(>250)$

(b) Labor force characteristics

Share women

Share white-collar workers

Share temporary workers

Share high-skilled workers

Share part time

(c) Absenteeism

Average worker
White collar
Blue collar
North
Center
South
Industry
Services

Small $(<50)$

Medium (50-250)

Large (>250)

(d) Labor market characteristics

Unemployment rate

North

Center

South

Industrial district

North

Center

South

Metropolitan area

North

Center

South
Mean

$S D$

53.17

28.49

1032

0.41

0.67

0.79

0.35

0.26

0.28

0.28

0.50

0.38

0.45

0.17

0.15

0.09

0.55

0.17

0.28

0.25

0.19

0.38

0.09

0.07

0.20

0.08

0.10

0.06

0.05

$0.051 \quad 0.032$

$0.042 \quad 0.021$

$0.071 \quad 0.044$

$0.051 \quad 0.031$

$0.051 \quad 0.030$

$0.052 \quad 0.034$

$0.052 \quad 0.030$

$0.044 \quad 0.029$

$0.043 \quad 0.031$

$0.056 \quad 0.026$

$0.064 \quad 0.025$

$0.042 \quad 0.018$

$0.038 \quad 0.007$

$0.053 \quad 0.015$

$0.114 \quad 0.028$

$0.362 \quad 0.481$

$0.362 \quad 0.481$

$\begin{array}{ll}0.480 & 0.501\end{array}$

$0.060 \quad 0.238$

$\begin{array}{ll}0.327 & 0.469\end{array}$

$0.351 \quad 0.478$

$0.152 \quad 0.360$

$0.214 \quad 0.413$

Italian firms (ISTAT-ASIA 2008)

Industry and employees $>15$

(75 percent of our sample)

NotE: Value added and capital stocks are in millions of euro. Absenteeism at firm level is the average amount of hours of absence as a percentage of contractual working hours. Data on value added and capital stock are drawn from the AIDA database; absenteeism and workforce composition are calculated using information from Confindustria database. Data on the local rate of unemployment and productive characteristics are obtained from the SLLs database (ISTAT). 
TABLE 2

Wage Bill Structure

\begin{tabular}{lcccccc}
\hline \hline & $\begin{array}{c}\text { Annual } \\
\text { wage } \\
(1)\end{array}$ & $\begin{array}{c}\text { Industry } \\
\text { share } \\
(2)\end{array}$ & $\begin{array}{c}\text { Super-minimum } \\
(3)\end{array}$ & $\begin{array}{c}\text { Production } \\
\text { bonus } \\
(4)\end{array}$ & $\begin{array}{c}\text { Variable } \\
\text { premium } \\
(5)\end{array}$ & $\begin{array}{c}\text { Firm share } \\
(\text { cols. 3+4+5) } \\
(6)\end{array}$ \\
\hline Average worker & 29024 & 0.812 & 0.129 & 0.023 & 0.036 & 0.188 \\
White collar & 34855 & 0.747 & 0.197 & 0.023 & 0.033 & 0.253 \\
Blue collar & 25379 & 0.856 & 0.086 & 0.021 & 0.037 & 0.144 \\
Manufacturing & 28984 & 0.808 & 0.131 & 0.026 & 0.035 & 0.192 \\
Services & 29449 & 0.826 & 0.118 & 0.016 & 0.040 & 0.174 \\
Small firm & 27759 & 0.810 & 0.132 & 0.023 & 0.034 & 0.190 \\
Medium firm & 29323 & 0.811 & 0.132 & 0.025 & 0.033 & 0.189 \\
Large firm & 31299 & 0.807 & 0.118 & 0.035 & 0.039 & 0.193 \\
\hline
\end{tabular}

NoTE: Annual wage is in euros. Information on wage bill structure is from the Confindustria labor market survey.

\section{Results}

Three-stage least-squares pooled estimation results. The three-stage leastsquares (3SLS) approach allows estimating the production function equation (equation 4) and the effort equation (equation 5) simultaneously, treating both firm productivity and absenteeism as endogenous. Tables 3 and $4^{18}$ show the results. In each table, column (1) reports the unweighted estimates, while in column (2) the observations belonging to the two surveys (2008 and 2009) are weighted differently, so that the results are not driven by the 2009 data. Specifically, the weights are the inverse of the number of observations by year, so that both years have the same impact on the final results.

The Cobb-Douglas production function fits well the data and the estimated coefficients have the expected sign. The fact that the coefficient of labor is higher than the textbook expectation is usually explained in the growth accounting tradition by the fact that we should consider also human capital together with the physical capital stock ${ }^{19}$ and is in line with previous empirical works at firm level (Konings and Vanormelingen 2010). Moreover, our specification of labor as effort augmented is not rejected by the data so that the labor

\footnotetext{
${ }^{18} \mathrm{We}$ use progressive sub numerations for tables belonging to same estimation; that is, 1.1, 1.2, and progressive numeration for tables reporting results belonging to different estimations, that is 1, 2, 3. All regressions include year, macroregion, and industry dummies. Firms are classified according to the industry classification identified by the national collective agreement (Contratto Collettivo Nazionale del Lavoro [CCNL]) applied in the company. We define ten productive sectors: food and beverages; textiles; footwear and leather products; rubber and plastic products; chemical and pharmaceutical products; metalworking; other manufacturing sectors; construction; trade, transport and telecommunication; other service.

19 See for instance Caselli 2005.
} 
TABLE 3

Production Function With One Type of Worker: 3SLS Results

\begin{tabular}{lcc} 
Dependent variable: value added & Pooled estimation $(1)$ & Pooled weighted (2) \\
\hline Labor input $(E=e L)$ & $0.606(0.049)^{* * * * *}$ & $0.676(0.037)^{* * * *}$ \\
Physical capital stock & $0.186(0.025)^{* * *}$ & $0.204(0.021)^{* * *}$ \\
Share temporary workers & $0.354(0.490)$ & $0.386(0.452)$ \\
Share white-collar workers & $0.837(0.177)^{* * *}$ & $0.814(0.111)^{* * *}$ \\
Share graduate workers & $1.022(1.107)$ & $0.598(0.720)$ \\
Share temporary $\times$ Share graduate & $-4.443(3.366)$ & $-2.841(1.925)$ \\
Share temporary $\times$ Share white & $-0.810(1.573)$ & $-0.885(1.138)$ \\
Share white $\times$ Share graduate & $-1.024(0.898)$ & $-0.586(0.885)$ \\
Year dummies & Yes & Yes \\
Industry dummies & Yes & Yes \\
Macro-regional dummies & Yes & Yes \\
Observations & 2098 & 2098 \\
Number of firms & 1920 & 1920 \\
$R^{2}$ & 0.58 & 0.70 \\
$p$-value $l=e$ & 0.46 & 0.25
\end{tabular}

Note: $* * * * * *$ Indicate significance at 1,5 and 10 percent. Clusterized robust standard errors (264 clusters) appear in parentheses. Labor input and capital stock are instrumented with their lagged values. Estimation of equation (4).

input measured as number of workers in full-time equivalent units, and the effort indicator has the same coefficients. ${ }^{20}$

More qualified workers (white collar) are more productive than blue collar with a productive premium of being white collar of about 20 percent. The presence of a higher share of graduates has a positive effect although not significant at conventional levels. Temporary forms of employment do not appear to have a significant direct effect on productivity. We also include interactions among the different types of human capital (the share of white-collar, temporary, and graduate workers) to capture the presence of complementarities among them, that is, the productivity gains of graduate workers is affected by the composition of the labor force inside the firm in terms of type of occupation (white collar versus blue collar) and/or in terms of the type of contract. The coefficients of the interactions terms are all negative and not significant at conventional levels.

The coefficients of the effort equation are presented in Table 4. Wage flexibility appears to have a negative impact on the average level of effort inside the firm, although the coefficient is only marginally significant and becomes

\footnotetext{
${ }^{20}$ The restriction on equality of the coefficients of labor $(L)$ and effort $(e)$ is tested through an $F$-test and then imposed in the model. We also test the presence of the constant return to scales (CRS) hypothesis, which is rejected by the data.
} 


\section{0 / Michele Battisti and Giovanna Vallanti}

TABLE 4

Effort Equation With One Type of Worker: 3SLS Results

\begin{tabular}{|c|c|c|}
\hline Dependent variable: workers' effort & $\begin{array}{l}\text { Pooled estimation } \\
\text { (1) }\end{array}$ & $\begin{array}{l}\text { Pooled weighted } \\
\text { (2) }\end{array}$ \\
\hline \multicolumn{3}{|l|}{ Wage flexibility } \\
\hline Share variable wage premium & $-0.056(0.031)^{*}$ & $-0.046(0.031)$ \\
\hline Share other wage premium & $0.007(0.023)$ & $0.022(0.024)$ \\
\hline Super minimum differential & $0.000(0.000)$ & $0.001(0.001)$ \\
\hline Seniority differential & $-0.001(0.000)$ & $-0.001(0.000)$ \\
\hline \multicolumn{3}{|l|}{ Numerical flexibility } \\
\hline Risk of dismissals & $-0.028(0.015)^{*}$ & $-0.035(0.016)^{* *}$ \\
\hline Hiring rate & $-0.000(0.003)$ & $0.002(0.003)$ \\
\hline Share of temporary hiring & $-0.005(0.002)^{* *}$ & $-0.008(0.003)^{* * *}$ \\
\hline Share of temporary workers & $-0.038(0.014)^{* * *}$ & $-0.068(0.016)^{* * *}$ \\
\hline Share of temporary workers*trans. & $0.109(0.042)^{* * *}$ & $0.208(0.047)^{* * * *}$ \\
\hline Share of apprenticeship & $-0.007(0.015)$ & $-0.013(0.017)$ \\
\hline Share of collaborators & $-0.009(0.009)$ & $-0.010(0.010)$ \\
\hline Share of part-time workers & $0.002(0.012)$ & $-0.023(0.012)^{*}$ \\
\hline Share of agency workers & $-0.0001(0.000)^{* *}$ & $-0.0001(0.000)^{* *}$ \\
\hline \multicolumn{3}{|l|}{ Labor and firm characteristics } \\
\hline Presence of a senior manager & $-0.003(0.002)$ & $-0.002(0.002)$ \\
\hline Share of women & $-0.031(0.005)^{* * * *}$ & $-0.027(0.005)^{* * *}$ \\
\hline Share of white-collar workers & $0.031(0.005)^{* * *}$ & $0.034(0.005)^{* * * *}$ \\
\hline Firm size & $-0.016(0.004)^{* * *}$ & $-0.014(0.004)^{* * *}$ \\
\hline Firm size ${ }^{2}$ & $0.001(0.000)^{* * *}$ & $0.001(0.000)^{* * * *}$ \\
\hline \multicolumn{3}{|l|}{ Institutional and labor market characteristics } \\
\hline Art. 18 & $0.001(0.003)$ & $-0.003(0.003)$ \\
\hline Unemployment rate by province 2006 & $0.000(0.001)$ & $0.000(0.001)$ \\
\hline Metropolitan area & $-0.003(0.002)$ & $-0.004(0.002)^{*}$ \\
\hline Presence of an industrial district & $0.001(0.002)$ & $0.001(0.002)$ \\
\hline Year dummies & Yes & Yes \\
\hline Industry dummies & Yes & Yes \\
\hline Macro-regional dummies & Yes & Yes \\
\hline Observations & 2098 & 2098 \\
\hline Number of firms & 920 & 1920 \\
\hline$R^{2}$ & 0.15 & 0.14 \\
\hline
\end{tabular}

Note: $* * *, * *, *$ Indicate significance at 1,5 and 10 percent. Clusterized robust standard errors (264 clusters) appear in parentheses.

Estimation of equation (5)

not significant in the sample-weighted regression. Also, the other monetary forms of incentivation do not have a significant impact on effort.

Considering the effect of numerical flexibility on permanent workers' effort, we can see that the level of absenteeism increases with the share of temporary workers employed by the firms both if we consider the flow (temporary hirings) and the change in the stock. Moreover, such effect appears to be quantitatively and qualitatively the same whatever type of temporary contract 
we consider (i.e., fixed-term employment contracts or atypical contracts such as external collaborations and agency contracts). The negative effect of fixedterm contracts is decreasing with the probability for a temporary worker of obtaining a permanent position with the current employer and becomes positive when the conversion rate into a permanent position is above 35 percent. $^{21}$

As our measure of effort concerns permanent workers only, this result suggests that a high degree of job instability may be detrimental for the effort and motivation of those who hold a permanent position. Theoretically, this may be explained by arguing that when temporary employment is used as a buffer for permanent employment, workers with a permanent position in the firm have a higher incentive to shirk because the workforce adjustments in case of negative shocks will be primarily carried out through changes in temporary worker flows. ${ }^{22}$ Moreover, there is a large socioeconomic literature that relates workers' effort to the working environment characteristics and to coworkers' behavior. This strand of literature predicts that an increase in the degree of uncertainty and precariousness inside the firm may lead to a deterioration in the working environment, reduce workers' cooperation, and undermine workers' motivations and effort.

To control for the effects of legislative protection on workers' shirking behavior, we use a dummy variable (art_18 in Table 4 and following tables), which assumes value 1 for firms with a number of employees larger than 15 and zero otherwise. This dummy captures the effect of employment protection legislation, as firing costs are significantly lower in firms with fewer than sixteen employees in Italy. After controlling for firm size, the coefficient of the dummy variable for EPL strictness is not significant at conventional levels. On the other hand, absenteeism increases with the firm size at a decreasing rate. The negative side effect on effort can be due both to differences in the degree of workers' protection due to differences in the legislation regulating dismissals as well as to a higher degree of unionization of large firms (Origo 2009) and to difficulties of monitoring performance in large organizations. ${ }^{23}$ Finally, considering workforce characteristics, higher absenteeism is related to

\footnotetext{
${ }^{21}$ The conversion rate is calculated as the share of fixed-term contracts that became permanent during the current and previous year over the total numbers of such contracts that existed during the same period. In our sample, $<30$ percent of the firms which employ individuals on a temporary basis report a value above the 35 percent threshold.

22 According to Goux, Maurin, and Pauchet (2001), when temporary employment is used as a buffer for permanent employment, establishments foreseeing a decline in net employment in the long run opt to increase their temporary job or worker flows to accommodate their current demands while still keeping future dismissal costs low.

23 A demand side explanation of the effect of size on absenteeism is put forward by Barmby and Stephan (2000) who argue that larger firms are able to diversify risk from absence more easily than small firms and this implies a lower propensity of contrasting absenteeism by the large firms.
} 


\section{2 / Michele Battisti and Giovanna Vallanti}

a large share of part-time workers, a large share of women (this result is in line with Ichino and Moretti 2009), and a large share of blue-collar workers.

In the second specification of the empirical model (equations 11-13), we remove the assumption of perfect substitutability between white- and bluecollar workers and estimate separately the effort equations for the two types of workers. The results of the 3SLS regressions are reported in Tables 5-7.

The estimated coefficients of the production function are in line with the previously reported estimates. Interestingly, the coefficients of the interaction terms of the labor inputs (white-collar and blue-collar workers) with the share of graduate workers are significantly different from zero and with an opposite sign. This suggests that the productivity gains from the highly educated work force are stronger in firms with a larger number of workers involved in administrative/clerical jobs and decline with the number of workers involved in manual tasks, implying complementarities between high level of education and high-skill occupations. Considering the effort equation of the white-collar workers (Table 6), a larger share of the variable wage premium (which is the share of remuneration linked to firms' performance) and other wage premia (linked to individual performance) have a positive and significant effect on workers' effort (through lower absenteeism). Moreover, as in the aggregate case, the share of fixed-term contracts is negatively signed, suggesting that job

TABLE 5

Production Function With Two Types of Workers: 3SLS Results

\begin{tabular}{lcc}
\hline \hline & Pooled estimation & Pooled weighted \\
Dependent variable: value added & $(1)$ & $(2)$ \\
\hline Labor input ${ }_{\text {WHITE }}(E=e L)$ & $0.426(0.047)^{* * * *}$ & $0.446(0.031)^{* * *}$ \\
Labor input ${ }_{\text {BLUE }}(E=e L)$ & $0.198(0.038)^{* * * *}$ & $0.249(0.029)^{* * *}$ \\
Physical capital stock & $0.191(0.026)^{* * *}$ & $0.210(0.020)^{* * *}$ \\
Share temporary workers & $-0.151(0.746)^{* *}$ & $-0.069(0.631)$ \\
Share graduate workers & $1.068(0.683)^{* *}$ & $1.014(0.561)^{* *}$ \\
Share temporary $\times$ Share white & $-0.381(0.240)$ & $-0.244(0.208)$ \\
Share temporary $\times$ Share blue & $-0.810(1.355)$ & $-0.885(1.130)$ \\
Share white $\times$ Share graduate & $0.108(0.127)$ & $0.222(0.120)^{* *}$ \\
Share blue $\times$ Share graduate & $-0.355(0.185)^{* *}$ & $-0.491(0.158)^{* * *}$ \\
Year dummies & Yes & Yes \\
Industry dummies & Yes & Yes \\
Macro-regional dummies & Yes & Yes \\
Observations & 2098 & 2098 \\
Number of firms & 1920 & 1920 \\
$R^{2}$ & 0.58 & 0.70 \\
$p$-value $l=e$ & 0.19 & 0.26 \\
\hline
\end{tabular}

Note: $* * *, * *, *$ Indicate significance at 1,5 and 10 percent. Clusterized robust standard errors (264 clusters) appear in parentheses. Labor input and capital stock had been instrumented with their lagged values.

Estimation of equation (11). 
TABLE 6

Effort Equation With Two Types of Workers: White-Collar Workers

\begin{tabular}{|c|c|c|}
\hline Dependent variable: white-collar workers' effort & $\begin{array}{l}\text { Pooled estimation } \\
\text { (1) }\end{array}$ & $\begin{array}{l}\text { Pooled weighted } \\
\text { (2) }\end{array}$ \\
\hline \multicolumn{3}{|l|}{ Wage flexibility } \\
\hline Share variable wage premium & $0.078(0.034)^{* *}$ & $0.091(0.041)^{* *}$ \\
\hline Share other wage premium & $0.042(0.034)$ & $0.086(0.028)^{* * * *}$ \\
\hline Super minimum differential & $0.000(0.001)$ & $0.001(0.001)$ \\
\hline Seniority differential & $-0.001(0.001)$ & $-0.001(0.001)$ \\
\hline \multicolumn{3}{|l|}{ Numerical flexibility } \\
\hline Risk of dismissals & $-0.034(0.019)^{*}$ & $-0.056(0.030)^{*}$ \\
\hline Hiring rate & $-0.005(0.003)$ & $0.004(0.004)$ \\
\hline Share of temporary hiring & $-0.001(0.003)$ & $-0.002(0.003)$ \\
\hline Share of temporary workers & $-0.058(0.027)^{* *}$ & $-0.074(0.036)^{* *}$ \\
\hline Share of temporary workers*trans. & $0.130(0.058)^{* *}$ & $0.236(0.075)^{* * *}$ \\
\hline Share of apprenticeship & $-0.004(0.021)$ & $-0.014(0.019)$ \\
\hline Share of collaborators & $0.007(0.016)$ & $-0.003(0.012)$ \\
\hline Share of part-time workers & $-0.006(0.015)$ & $-0.022(0.015)$ \\
\hline Share of agency workers & $-0.000(0.000)$ & $-0.000(0.000)$ \\
\hline \multicolumn{3}{|l|}{ Labor and firm characteristics } \\
\hline Presence of a senior manager & $0.000(0.003)$ & $0.001(0.003)$ \\
\hline Share of women & $-0.018(0.006)^{* * * *}$ & $-0.014(0.006)^{* *}$ \\
\hline Share of white-collar workers & $-0.007(0.006)$ & $-0.009(0.007)$ \\
\hline Share of graduate workers & $-0.033(0.013)^{* * *}$ & $-0.029(0.016)^{* *}$ \\
\hline Firm size & $-0.015(0.005)^{* * *}$ & $-0.016(0.005)^{* * * *}$ \\
\hline Firm size ${ }^{2}$ & $0.001(0.000)^{* *}$ & $0.001(0.000)^{* *}$ \\
\hline \multicolumn{3}{|l|}{ Institutional and labor market characteristics } \\
\hline Art. 18 & $0.004(0.005)$ & $0.006(0.004)$ \\
\hline Unemployment rate & $0.001(0.001)$ & $0.002(0.001)^{* *}$ \\
\hline Metropolitan area & $-0.001(0.003)$ & $-0.002(0.003)$ \\
\hline Presence of an industrial district & $0.001(0.003)$ & $0.002(0.003)$ \\
\hline Year dummies & Yes & Yes \\
\hline Industry dummies & Yes & Yes \\
\hline Macroregional dummies & Yes & Yes \\
\hline Observations & 2098 & 2098 \\
\hline Number of firms & 1920 & 1920 \\
\hline$R^{2}$ & 0.07 & 0.08 \\
\hline
\end{tabular}

Note: ***,**,* Indicate significance at 1,5 and 10 percent. Clusterized robust standard errors (264 clusters) appear in parentheses.

Estimation of equation (12).

instability is detrimental to workers' effort when the conversion rate to permanent employment is low. Finally, the coefficient of the unemployment rate in the local labor market is positive and statistically significant, implying more effort when the outside options are less favorable.

The effects of numerical flexibility on blue-collar workers' effort (Table 6) are qualitatively similar, with some differences in the magnitude and significance of the estimated parameters. Differently from the white-collar workers' 


\section{4 / Michele Battisti and Giovanna Vallanti}

TABLE 7

Effort Equation With Two Types of Workers: Blue-Collar Workers

\begin{tabular}{|c|c|c|}
\hline Dependent variable: blue-collar workers' effort & $\begin{array}{l}\text { Pooled estimation } \\
\text { (1) }\end{array}$ & $\begin{array}{l}\text { Pooled weighted } \\
\text { (2) }\end{array}$ \\
\hline \multicolumn{3}{|l|}{ Wage flexibility } \\
\hline Share variable wage premium & $-0.021(0.037)$ & $0.001(0.026)$ \\
\hline Share other wage premium & $-0.006(0.005)$ & $-0.006(0.005)$ \\
\hline Super minimum differential & $0.000(0.001)$ & $0.001(0.001)$ \\
\hline Seniority differential & $-0.001(0.001)$ & $-0.001(0.001)$ \\
\hline \multicolumn{3}{|l|}{ Numerical flexibility } \\
\hline Risk of dismisals & $-0.001(0.019)$ & $-0.016(0.020)$ \\
\hline Hiring rate & $0.003(0.003)$ & $0.006(0.004)$ \\
\hline Share of temporary hiring & $-0.009(0.004)^{* *}$ & $-0.007(0.003)^{* *}$ \\
\hline Share of temporary workers & $-0.046(0.023)^{* *}$ & $-0.080(0.030)^{* * *}$ \\
\hline Share of temp. workers*trans. & $0.127(0.052)^{* *}$ & $0.204(0.068)^{* * *}$ \\
\hline Share of apprenticeship & $-0.017(0.021)$ & $-0.022(0.026)$ \\
\hline Share of collaborators & $-0.020(0.011)^{*}$ & $-0.021(0.012)^{*}$ \\
\hline Share of part-time workers & $-0.007(0.016)$ & $-0.030(0.025)$ \\
\hline Share of internal workers & $-0.000(0.000)^{* * * *}$ & $-0.000(0.000)^{* *}$ \\
\hline \multicolumn{3}{|l|}{ Labor and firm characteristics } \\
\hline Presence of a senior manager & $-0.006(0.003)^{* *}$ & $-0.006(0.004)$ \\
\hline Share of women & $-0.024(0.006)^{* * *}$ & $-0.021(0.007)^{* * *}$ \\
\hline Share of white-collar workers & $-0.038(0.006)^{* * *}$ & $0.042(0.007)^{* * * *}$ \\
\hline Share of graduate workers & $-0.008(0.012)$ & $-0.008(0.016)$ \\
\hline Firm size & $-0.018(0.004)^{\text {**** }}$ & $-0.014(0.006)^{* * * *}$ \\
\hline Firm size ${ }^{2}$ & $0.001(0.000)^{* *}$ & $0.001(0.000)^{*}$ \\
\hline \multicolumn{3}{|l|}{ Institutional and labor market characteristics } \\
\hline Art. 18 & $0.000(0.004)$ & $-0.004(0.005)$ \\
\hline Unemployment rate & $0.001(0.001)$ & $0.001(0.001)$ \\
\hline Metropolitan area & $0.001(0.001)$ & $-0.003(0.003)$ \\
\hline Presence of an industrial district & $0.000(0.002)$ & $0.001(0.003)$ \\
\hline Year dummies & Yes & Yes \\
\hline Industry dummies & Yes & Yes \\
\hline Macroregional dummies & & Yes \\
\hline Observations & 2098 & 2098 \\
\hline Number of firms & 1920 & 1920 \\
\hline$R^{2}$ & 0.15 & 0.15 \\
\hline
\end{tabular}

Note: $* * *, * *, *$ Indicate significance at 1,5 and 10 percent. Clusterized robust standard errors (264 clusters) appear in parentheses.

Estimation of equation (13).

effort equation, blue-collar workers' effort is not significantly affected by monetary incentives, all the controls for wage flexibility being not significant. This different response to monetary incentive may be due to differences in the risk attitude of blue-collar workers (Prendergast 1999; Sloof and van Praag 2008) as well as differences in skill endowments (Bonner and Sprinkle 2002).

Finally, to control for firm-specific time-invariant fixed effects, Table 8 reports the regressions of the effort equations (aggregate, white collar, and blue collar) in first differences rather than in levels for a restricted sample 
TABLE 8

Effort Equations Robustness Checks: First Differences Estimation

\begin{tabular}{lccr}
\hline \hline & $\begin{array}{c}\text { Effort } \\
(1)\end{array}$ & $\begin{array}{c}\text { Effort white collar } \\
(2)\end{array}$ & $\begin{array}{c}\text { Effort blue collar } \\
(3)\end{array}$ \\
\hline Wage flexibility & & & \\
Share variable wage premium & $0.057(0.053)$ & $0.190(0.045)^{* * *}$ & $-0.012(0.136)$ \\
Share other wage premium & $-0.017(0.048)$ & $0.070(0.060)$ & $-0.004(0.056)$ \\
Super minimum differential & $0.001(0.003)$ & $0.005(0.003)^{*}$ & $-0.001(0.004)$ \\
Seniority differential & $-0.001(0.003)$ & $-0.008(0.007)$ & $-0.006(0.004)$ \\
Numerical flexibility & & & \\
Risk of dismissals & $0.030(0.013)^{*}$ & $0.037(0.013)^{* * *}$ & $0.042(0.012)^{* * *}$ \\
Hiring rate & $0.003(0.007)$ & $0.000(0.007)$ & $0.005(0.007)$ \\
Share of temporary hiring & $0.001(0.006)$ & $0.006(0.006)$ & $0.001(0.008)$ \\
Share of temporary workers & $-0.155(0.051)^{* *}$ & $-0.229(0.083)^{* *}$ & $-0.111(0.062)^{*}$ \\
Share of temporary workers*trans. & $0.356(0.118)^{* * *}$ & $0.439(0.176)^{* *}$ & $0.338(0.147)^{* *}$ \\
Share of apprenticeship & $-0.033(0.053)$ & $-0.103(0.068)$ & $-0.018(0.050)$ \\
Share of collaborators & $-0.002(0.020)$ & $0.005(0.011)$ & $0.010(0.037)$ \\
Share of part-time workers & $0.002(0.032)$ & $0.010(0.018)$ & $-0.015(0.081)$ \\
Share of internal workers & $-0.000(0.000)$ & $-0.000(0.000)$ & $-0.000(0.000)$ \\
Labor and firm characteristics & & & \\
Presence of a senior manager & $-0.007(0.009)$ & $-0.004(0.011)$ & $-0.008(0.009)$ \\
Share of women & $-0.043(0.017)^{* * *}$ & $-0.017(0.012)$ & $-0.045(0.021)^{* *}$ \\
Share of white-collar workers & $0.035(0.012)^{* * *}$ & $-0.019(0.009)^{* *}$ & $0.024(0.013)^{*}$ \\
Share of graduate workers & $0.001(0.014)$ & $0.001(0.015)$ & $-0.004(0.020)$ \\
Firm size & $-0.023(0.008)^{* * * *}$ & $-0.015(0.008)^{* *}$ & $-0.027(0.010)^{* * *}$ \\
Firm size ${ }^{* * *}$ & $0.002(0.001)^{* *}$ & $0.001(0.001)$ & $0.002(0.001)^{*}$ \\
Observations & 356 & 356 & 356 \\
Number of firms & 178 & 178 & 178 \\
$R^{2}$ & 0.24 & 0.15 & 0.23 \\
\hline
\end{tabular}

Note: $* * *, * * *$ Indicate significance at 1,5 and 10 percent. Standard errors appear in parentheses.

of firms. ${ }^{24}$ We still find a positive and statistically significant effect of the variable wage premium on white-collar workers' effort and a negative effect of temporary employment on both white-collar and blue-collar workers' effort. This seems to confirm the previous conclusions that wage flexibility can have a positive impact on effort and then on firm productivity, while numerical flexibility is detrimental for productivity through the negative impact on effort.

Panel data two-step procedure and results. The pooled 3SLS regression approach has two shortcomings. First, given the cross-section characteristic of our database, we are not able to control for firm-specific time-invariant compo-

\footnotetext{
${ }^{24}$ The number of observations for which data are available for both 2008 and 2009 is restricted to 178 firms. In Table 8, we report first difference estimation of the effort equations for this sample of firms and show that our main results are robust after controlling for firm-specific fixed effects.
} 


\section{6 / Michele Battisti and Giovanna Vallanti}

nents and this may bias the results. Moreover, as we already stressed, absenteeism may not be the only dimension through which flexibility affects firm performance. To address these two issues, we substitute (2) into (1) and we estimate a reduced form equation relying upon a two-step procedure proposed by Black and Lynch (2001) in a similar analysis.

In the first step, we exploit the longitudinal dimension of the AIDA database and estimate a production function using data on value added, capital, and workers which are available over the period 2000-2009. ${ }^{25}$ This allows us to obtain robust estimates of the parameters on labor and capital. We then use the estimated firm-specific time-invariant component of the residual in the second step to identify the direct effect of quasi-time-invariant firm-level regressors such as remuneration policy, human resources policies, and other time-invariant characteristics on a broad indicator of firm productivity.

Solving equation (1) and (2), we obtain the following reduced form equation:

$$
\ln Y_{i, t}=\alpha \ln K_{i, t}+\beta \ln L_{i, t}+\gamma \theta_{i}+\vartheta_{i, t},
$$

where the error term can be decomposed into two parts

$$
\vartheta_{i, t}=v_{i}+\varepsilon_{i, t} \text {. }
$$

In equations (14) and (15) $\theta_{i}$ is a vector of firm characteristics, which includes the vector $\mathbf{Z}_{i}$ of the effort's determinants as in equation (2), $v_{i}$ is an observed time-invariant firm-specific component, and $\varepsilon_{i, t}$ is an error term. In particular $\theta_{i}$ includes firms' wage strategy (such as the share of performance-related payments), human capital composition (skilled vs. unskilled workers, and white- versus blue-collar workers), and flexible work practices (type of contracts), which may influence firm productivity through unobservable effort.

Therefore, as in Black and Lynch (2001), we adopt the following two-step procedure. In the first step, we obtain a robust estimation of the parameters $\alpha$ and $\beta$, compute the predicted values of equation (12) and then an estimate of the $\gamma \theta_{i}+v_{i}+\varepsilon_{i, t}$ term. Averaging this latest term over time, we obtain an estimate of the firm-specific time-invariant component of the residual. ${ }^{26}$ In the second step, we regress the average residual on the vector $\mathbf{Z}_{i}$, human capital composition, industry and regional dummies. This two-step procedure allows us to estimate the second step without the possible sources of biases arising from capital and labor correlations with time-invariant effect $v_{i}$.

\footnotetext{
${ }^{25}$ After matching the longitudinal information from AIDA for the period 2000-2009 with the data from the Confindustria survey we end up with a final estimation sample of 1820 firms.

${ }^{26}$ That is defined as technical efficiency in Schmidt and Sickles (1984).
} 
To run the first-step coefficients, we use the system generalized method of moments (GMM) estimator described by Blundell and Bond (2000) and Bond (2002), which overcomes the limitations of standard panel estimators (fixed effect and first-differenced GMM estimator), that is, unreliable low values of the production factors parameters when the production factors (employment and capital) are highly persistent. ${ }^{27}$

GMM system estimates in the first step are reported in the first panel of Table 9. A cursory look of the table reveals that the regression is highly significant, standard specification tests hold, ${ }^{28}$ and constant return to scale is not accepted. As expected, the estimated coefficient on the capital stock is now larger than the one reported in Table 3, while that on the labor input is smaller. ${ }^{29}$ Using these first-step estimates, we calculate the average residual for each firm in the sample.

The second panel of Table 9 shows the second-step results, obtained from regressing the average residuals on the controls that were previously included in the effort equations. Such regressions allow us to check whether monetary incentives and numerical flexibility have a direct and significant effect on firm productivity once we control for unobserved time-invariant characteristics in the production function. The results appear qualitatively similar to those obtained using the three-stage least-squares technique in Tables 6 and 7. As expected, given the different definition of the left-hand side variable, which is a much broader indicator of productivity than absenteeism, we see that the estimated coefficients appear larger in magnitude. In line with the 3SLS

\footnotetext{
${ }^{27}$ Following Blundell and Bond (2000), equation (14) could have a dynamic common factor representation with the lagged value of $Y$ in the right-hand side correlated with the fixed-effect component of the error term in (15). Two standard alternative strategies to avoid the endogeneity problem are the first-differenced GMM estimator (Arellano and Bond 1991) and the system GMM estimator (Blundell and Bond 1998). In the standard first-differenced GMM estimator lagged first differences of all the variables are used as instruments for the equations after eliminating the $v_{i}$ term through differentiation. However, the first-differenced GMM estimator has been found to have poor finite sample properties (bias and imprecision) when the lagged levels of the series are only weakly correlated with subsequent first differences (this is the case when employment and capital are highly persistent). As highlighted in Blundell and Bond (2000) and Bond (2002), system GMM procedure outperforms the standard first-differenced GMM by combining moment conditions for the model in first differences with moment conditions for the model in levels. Results using the standard fixed-effect estimator and the first-differenced GMM estimator are qualitatively similar to those obtained using the system GMM procedure and are available from the authors on request.

${ }^{28}$ The common factor test shows that the nonlinear restrictions implied by the dynamic representation of production function with an autoregressive error component is not rejected and the difference version of the Sargan test accepts the validity of the instruments. Both of these tests are in line with the results of Blundell and Bond (2000).

29 The coefficients on capital and labor cannot be exactly compared with those in Table 1 also because in this second set of regressions the sample is different (slightly smaller), and we are not controlling for the quality of the labor input (human capital, effort, and the share of white-collar workers) when we estimate the production function.
} 
TABLE 9

Robustness Checks: Two-Step System GMM Results

\begin{tabular}{lc}
\hline \hline First step: value added 2000-2009 & \\
Labor input $(E=e L)$ & $0.491(0.090)^{* * * * *}$ \\
Physical capital stock & $0.359(0.058)^{* * *}$ \\
Year dummies & Yes \\
Number of firms & 1820 \\
Observations & 11425 \\
Wald $\chi^{2}$ & $8032(0.000)$ \\
Comfact (prob.) & 0.21 \\
Difference Sargan (prob.) & 0.29 \\
Second step: WLS on averaged residuals & \\
Share variable wage premium white collar & $0.473(0.189)^{* *}$ \\
Share variable wage premium blue collar & $0.046(0.275)$ \\
Share other wage premium white collar & $0.160(0.180)$ \\
Share other wage premium blue collar & $-0.222(0.239)$ \\
Super minimum differentials & $0.011(0.006)^{*}$ \\
Seniority differential & $-0.009(0.002)^{* * * *}$ \\
Share of women & $-0.111(0.264)$ \\
Share of graduate workers & $0.221(0.056)^{* * * *}$ \\
Share of temporary workers & $0.038(0.103)^{* * *}$ \\
Share of temp. workers*trans. & $0.856(0.311)^{* * *}$ \\
Share of apprenticeship & $0.016(0.113)$ \\
Share of collaborators & $0.169(0.132)$ \\
Risk of dismissions & $0.001(0.008)$ \\
Presence of senior manager & $0.038(0.014)^{* * * *}$ \\
Share of part-time workers & $-0.081(0.099)$ \\
Unemployment rate & $-0.010(0.004)^{* *}$ \\
Size & $-0.024(0.017)$ \\
Size & $0.004(0.002)^{* * *}$ \\
Industry dummies & Yes \\
Regional dummies & Yes \\
Observations & 1988 \\
Number of firms & 1820 \\
$R^{2}$ & 0.090 \\
$F$-prob. & 0.000 \\
\hline & \\
\hline &
\end{tabular}

Note: ***,**, * Indicate significance at 1,5 and 10 percent. In the first step we use two lags of capital and labor as instruments. In the second step, clusterized robust standard errors (258 clusters) appear in parentheses.

Estimation of equation (14).

regressions, the presence of a performance-related premium for white-collar workers has a positive and significant effect on productivity, while the same premium paid to blue-collar workers has no impact on aggregate productivity.

As in the previous set of regressions, numerical flexibility is positively related to firm productivity only when conversion rates from temporary to permanent employment are high enough. ${ }^{30}$ This finding is consistent with the

\footnotetext{
${ }^{30}$ The threshold for conversion rate above which the effect of the share of temporary workers becomes positive and significant is around 20 percent.
} 
theoretical predictions that when fixed-term contracts are used as a screening device, they can be beneficial in terms of productivity because they improve the quality of the match between firms and workers and thus reduce turnover.

Structural equation modeling: An Alternative approach. In this section, we present an alternative way to estimate the effects of wage and numerical flexibility on productivity. We treat effort as an unobservable (latent) variable, and we use some observable variables that are potentially correlated with effort to model it and its impact on productivity. To this aim, we use the simultaneous equation modeling (SEM) technique. ${ }^{31}$

In line with the analysis developed in the previous section, we classify the exogenous (latent) determinants of effort as: wage flexibility $\xi_{1}$, numerical flexibility $\xi_{2}$, and workforce characteristics $\xi_{3}$. In turn, we assume that these latent exogenous variables influence some exogenous observables $x_{j}$ such as the share of variable wage premium or the share of temporary workers. Such observable variables are the effort determinants in the vector $\mathbf{Z}_{i}$ as in equation (2). The relationships among latent and observed variables represent the so-called measurement model, which is the following set of equations (in compact and logarithmic form) as follows: ${ }^{32}$

$$
\begin{gathered}
x_{j}=\phi_{j^{\prime}}^{\prime} \xi+\omega_{j} \\
y=\lambda e+\sum_{k=1}^{K} \beta_{k} x_{k}+\varepsilon
\end{gathered}
$$

In equation (16) $x_{j}$ are the observable exogenous variables, which are determined by the exogenous (latent) factors $\xi_{1,2,3}$ through $\phi .^{33}$ In (17) $y$ is value added; $x_{k}$ are manifest exogenous, that is, human and physical capital inputs which affect directly $y$; and $e$ is the endogenous latent variable that may represent a global measure of technical efficiency as well as omitted variables bias, with $\lambda$ being its impact coefficient on productivity. Finally $\omega_{j}$ and $\varepsilon$ are the error terms in equation (16) and (17), respectively.

The structural model links the exogenous latent determinants $\xi_{1,2,3}$ to the endogenous latent effort as follows:

$$
e=\gamma_{1} \xi_{1}+\gamma_{2} \xi_{2}+\gamma_{3} \xi_{3}+v
$$

\footnotetext{
${ }^{31}$ For a description see Bollen (1989); Corbetta (2002) and Kline (2010).

32 Suffix $i$ which identify firms is omitted to simplify the notation.

33 The exogenous variables included in the vector $\boldsymbol{x}_{\boldsymbol{j}}$ are the same regressors included in the vector $\mathbf{Z}$ as determinants of effort in equation (3). See page 6 for a full description of the variables.
} 


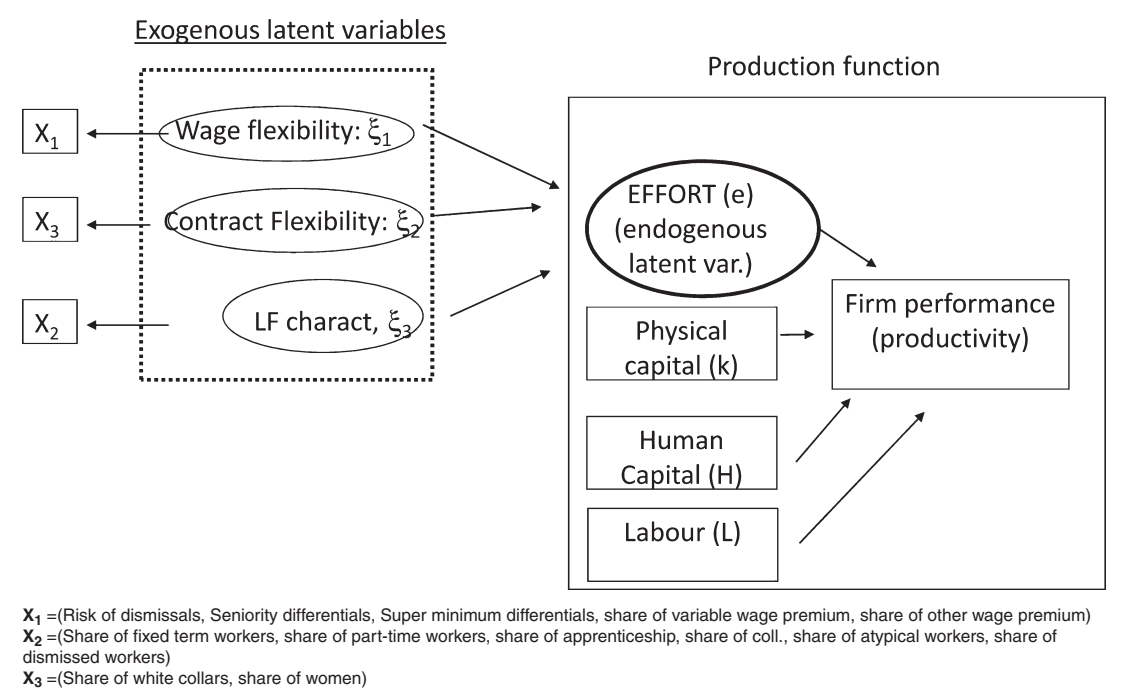

where $\gamma_{1,2,3}$ are the impact coefficients of the structural model and $v$ is the error term. Figure 1 shows the theoretical links among the latent (endogenous and exogenous) and the observed variables.

We then estimate the correlation matrices ${ }^{34}$ among variables and put a constraint for each equation containing a latent variable to identify the system. ${ }^{35}$ The model is estimated through maximum likelihood, while we use the confirmatory factor analysis to extract latent factors from the observed exogenous variables. We estimate the coefficients for the 2 years of the survey separately because we cannot include categorical variables to identify relevant common time-specific shocks that are relevant given the nature of our sample. Table 8 describes our results. In this case, we do not have separate tables for each equation but aggregate results for the whole system (Table 10). ${ }^{36}$

The results indicate that the regressions fit well the data and that the production function has coefficients very close to the 3SLS estimation. Beginning

\footnotetext{
${ }^{34}$ All the exogenous variables have the same scale because they are expressed in deviation from the means, which means that we have a correlation matrix instead of a covariance matrix.

${ }^{35}$ The model described by equations (16)-(18) has a structure that is similar to the 3SLS model we estimated in the previous section, except for the fact that we have endogenous latent variables on the right-hand side with coefficients $\phi, \lambda$. If we have identity equations among $y$ and $\mathbf{e}$ and $\mathbf{x}$ and $\xi$, then all the $x$ variables influence directly $y$ as in a standard reduced form estimation.

${ }^{36}$ We use the R package called sem, by Fox (2006).
} 
TABLE 10

Production Function: Structural Equation Modeling Results

\begin{tabular}{|c|c|c|}
\hline Dependent variable: value added & $\begin{array}{c}\text { Year } 2008 \\
\text { (1) }\end{array}$ & $\begin{array}{c}\text { Year } 2009 \\
\text { (2) }\end{array}$ \\
\hline \multicolumn{3}{|l|}{ Production function } \\
\hline Stock of labor & $0.697(0.021)^{* * *}$ & $0.437(0.029)^{* * * *}$ \\
\hline Physical capital stock & $0.264(0.021)^{* * *}$ & $0.239(0.029)^{* * *}$ \\
\hline Share graduate workers & $0.070(0.015)^{* * *}$ & $0.069(0.019)^{* * *}$ \\
\hline Effort & $0.093(0.027)^{* * *}$ & $0.324(0.606)$ \\
\hline \multicolumn{3}{|l|}{ Effort determinants } \\
\hline Wage flexibility & $0.814(0.372)^{* *}$ & $0.219(0.426)$ \\
\hline Numerical flexibility & $-0.467(0.285)^{*}$ & $-0.049(0.132)$ \\
\hline Labor and firm characteristics & 1.000 (constraint) & 1.000 (constraint) \\
\hline \multicolumn{3}{|c|}{ Wage flexibility (exogenous observed variables) } \\
\hline Seniority differentials & $0.218(0.069)^{* *}$ & $0.006(0.057)$ \\
\hline Super minimum differentials & $0.171(0.068)^{* *}$ & $0.005(0.058)$ \\
\hline Share of variable wage premium & $0.205(0.068)^{* *}$ & $0.197(0.047)^{* * *}$ \\
\hline Share of other variable premium & 1.000 (constraint) & 1.000 (constraint) \\
\hline \multicolumn{3}{|c|}{ Numerical flexibility (exogenous observed variables) } \\
\hline Share of fixed-term workers & $0.288(0.060)^{* * * *}$ & $0.124(0.047)^{* * *}$ \\
\hline Share of part-time workers & $0.141(0.071)^{* *}$ & $-0.017(0.041)$ \\
\hline Share of collaborators & $0.044(0.072)$ & $0.205(0.041)^{* * *}$ \\
\hline Share of atypical workers & $-0.076(0.071)$ & $-0.053(0.041)$ \\
\hline Share fired or dismissed workers & $-0.118(0.070)^{*}$ & $-0.016(0.040)$ \\
\hline Share of apprenticeship & 1.000 (constraint) & 1.000 (constraint) \\
\hline \multicolumn{3}{|c|}{ Labor characteristics (exogenous observed variables) } \\
\hline Share of women & $0.495(0.057)^{* * * *}$ & $-0.010(0.061)$ \\
\hline Share of white-collar workers & 1.000 (constraint) & 1.000 (constraint) \\
\hline Observations & 758 & 1631 \\
\hline Goodness of fit index & 0.75 & 0.78 \\
\hline$p$-value model $\chi^{2}$ & 0.000 & 0.000 \\
\hline
\end{tabular}

Note: $* * *, * * * *$ Indicate significance at 1,5 and 10 percent. Standard errors appear in parentheses.

Estimation of equations (16)-(18).

with the regressions with the 2008 data, the results show that the effort is significant and positively correlated with productivity. Moreover, the coefficients of the latent exogenous variables are consistent with the empirical findings of the previous sections. In particular, the results show that wage flexibility has a positive effect on effort and through effort on productivity, while numerical flexibility has an opposite impact. The results obtained using the 2009 data are qualitatively similar, although some coefficients are less significant.

\section{Conclusions}

This study has produced ecometric evidence on the relationships among flexible wage contracts, temporary jobs, and firm performance. The key results 


\section{2 / Michele Battisti and Giovanna Vallanti}

indicate that wage flexibility appears to have a positive and significant effect on effort and then (still positive) on firms' productivity. This is confirmed by additional checks based on GMM-based panel estimation where wage flexibility has a direct positive effect on productivity. Second, white-collar workers are more responsive to monetary incentives than blue-collar workers. Finally, we find that a higher share of temporary contracts has a negative impact on permanent workers' effort when the conversion rate of jobs from temporary to permanent is low. This may happen either because a larger share of fixed-term workers implies a lower dismissal probability for permanent workers, or because an increase in the degree of precariousness inside the firms can lead to a deterioration in the working environment and thus reduce workers' motivation and effort. This last effect has a (indirect) negative effect on firm productivity.

Our findings suggest a bigger role for reforms aimed to increase wage flexibility in enhancing firms' productivity, while those aimed to increase job flexibility through the introduction of temporary forms of employment are detrimental for productivity when such contracts are perceived as dead ends.

Such policy implications contrast with the reforming process which interested Italy in the last decade. In fact, the main labor market reforms have been mainly focused on providing flexibility at the margin by deregulating the use of atypical forms of employment. Only recently (July 2012), the Italian government introduced small changes in the firing procedures for open-ended employees, by relaxing the institution of discriminatory firing by extending monetary refund to a larger number of cases.

In contrast, reforms aimed to decentralize the wage setting mechanisms have been fewer, limited in scope, and slow in the implementation. However, under the pressure of the global recession, the Italian government has recently taken important steps in the direction of strengthening the responsiveness of wages to productivity. To this aim, a number of policy actions have been under discussion with all the social parties to promote wage bargaining decentralization and the introduction of tax incentives for productivity-based contracts.

\section{REFERENCES}

Arai, Mamhood, and Peter S. Thoursie. 2005. "Incentives and Selection in Cyclical Absenteeism." Labour Economics 12: 269-80.

Arellano, Manuel, and Stephen R. Bond. 1991. "Some Tests of Specification for Panel Data: Monte Carlo Evidence and an Application to Employment Equations." The Review of Economic Studies 58: 27797.

Barmby, Tim A., Chris D. Orme, and John G. Treble. 1991. "Worker Absenteeism: An Analysis Using Microdata." The Economic Journal 101(405): 214-29. 
_ and Gesine Stephan. 2000. "Worker Absenteeism: Why Firm Size May Matter." The Manchester School 68(5): 568-77.

Beatson, Mark. 1995. Labour Market Flexibility. Sheffield Employment Department Research Series, 48. Sheffield, England: The Employment Department.

Benito, Andrew, and Ignacio Hernando. 2008. "Labour Demand, Flexible Contracts and Financial Factors: Firm-Level Evidence from Spain.” Oxford Bulletin of Economics and Statistics 70(3): 283-301.

Black, Sandra E., and Lisa M. Lynch. 2001. "How to Compete: The Impact of Workplace Practices and Information Technology on Productivity." The Review of Economics and Statistics 83(3): 434-45.

Blanchard, Olivier J., and Augustin Landier. 2002. "The Perverse Effects of Partial Labour Market Reform: Fixed-Term Contracts in France.” Economic Journal 112(480): F214-44.

_ ment: The Aggregate Evidence.” Economic Journal 110(462): C1-33.

Blundell, Richard W., and Stephen R. Bond. 1998. "Initial Conditions and Moment Restrictions in Dynamic Panel Data Models." Journal of Econometrics 87: 115-43.

— , and —. 2000. "GMM Estimation with Persistent Panel Data: An Application to Production Functions." Econometric Reviews 19(3): 321-40.

Boeri, Tito, and Pietro Garibaldi. 2007. "Two Tier Reforms of Employment Protection: A Honeymoon Effect?" Economic Journal 117(521): F357-85.

Bollen, Kenneth A. 1989. Structural Equations with Latent Variables. New York, NY: Wiley Interscience.

Bond, Stephen. 2002. "Dynamic Panel Data Models: A Guide to Micro Data Methods and Practice." Portuguese Economic Journal 1(2): 141-62.

Bonner, Sarah E., and Geoffrey B. Sprinkle. 2002. "The Effects of Monetary Incentives on Effort and Task Performance: Theories, Evidence, and a Framework for Research." Accounting, Organizations and Society 27: 303-45.

Bradley, Steven, Colin Green, and Gareth D. Leeves. 2007. "Worker Absence and Shirking: Evidence from Matched Teacher-School Data." Labour Economics 14: 319-34.

Brown, Sarah, Fathi Fakhfakh, and John G. Sessions. 1999. "Absenteeism and Employee Sharing: An Empirical Analysis Based on French Panel Data, 1981-1991.” Industrial and Labor Relations Review 52: $234-51$.

— nomic Surveys 108: 23-53.

Burgess, Simon, Julia Lane, and David Stevens. 2000. "Job Flows, Worker Flows, and Churning." Journal of Labor Economics 18(3): 473-502.

Calmfors, Lars, and John Driffill. 1988. "Bargaining Structure, Corporatism and Macroeconomic Performance." Economic Policy 6: 12-61.

Cappelli, Peter, and Keith Chauvin. 1991. "An Interplant Test of the Efficiency Wage Hypothesis." The Quarterly Journal of Economics 106(3): 769-87.

Caselli, Francesco. 2005. "Accounting for Cross-Country Income Differences." In Handbook of Economic Growth, edited by P. Aghion, and S. Durlauf, pp. 679-741. Amsterdam, the Netherlands: Elsevier.

Clar, Miquel, Christian Dreger, and Raul Rams. 2007. "Wage Flexibility and Labour Market Institutions: A Meta-Analysis." Kyklos 60(2): 145-63.

Corbetta, Piergiorgio. 2002. Metodi di analisi multivariata per le scienze sociali. I modelli di equazioni strutturali. Bologna, Italy: Il Mulino.

Damiani, Mirella, and Andrea Ricci. 2008. Flexible Wage Contracts, and Firm Productivity: Evidence from Italy. Presented to AIEL Conference, Brescia, Italy.

Elia, L. 2010. "Temporary/Permanent Workers' Wage Gap: A Brand-new Form of Wage Inequality." Labour 24(2): 178-200.

Engellandt, Axel, and Regina T. Riphahn. 2005. "Temporary Contracts and Employee Effort." Labour Economics 12(3): 281-99.

Fox, John. 2006. "Structural Equation Modeling With the sem Package in R." Structural Equation Modeling 13(3): 465-86.

Fuss, Catherine. 2009. "What Is the Most Flexible Component of Wage Bill Adjustment? Evidence from Belgium.” Labour Economics 16: 320-29. 


\section{4 / Michele Battisti and Giovanna Vallanti}

Gielen, Anne C., Marcel J. Kerkhofs, and Jan C. Ours. 2010. "How Performance Related Pay Affects Productivity and Employment." Journal of Population Economics 23(1): 291-301.

Gomez-Mejia, Luis R., and David B. Balkin. 1989. "Effectiveness of Individual and Aggregate Compensation Strategies." Industrial Relations 28(3): 431-45.

Goux, Dominique, Eric Maurin, and Marianne Pauchet. 2001. "Fixed-term Contracts and the Dynamics of Labour Demand." European Economic Review 45: 533-52.

Guiso, Luigi, Luigi Pistaferri, and Fabiano Schivardi. 2005. "Insurance Within the Firm." Journal of Political Economy 113(5): 1054-87.

Heylen, Freddy. 1993. "Labour Market Structures, Labour Market Policy and Wage Formation in the OECD.” Labour 7(2): 25-51.

Ichino, Andrea, and Enrico Moretti. 2009. "Biological Gender Differences, Absenteeism and the Earning Gap.” American Economic Journal: Applied Economics 1(1): 183-218.

_ ism During and After Probation." Journal of the European Economic Association 3(1): 120-43.

Kline, Rex B. 2010. Principles and Practice of Structural Equation Modeling. New York, NY: Guilford Publications.

Konings, Jozef, and Stjin Vanormelingen. 2010. The Impact of Training on Productivity and Wages: Firm Level Evidence. IZA Discussion Papers 4731. Bonn, Germany: Institute for the Study of Labor (IZA).

Lazear, Edward P. 2000. "Performance Pay and Productivity." American Economic Review 90(5): 1346-61.

_ and Sherwin Rosen. 1981. "Rank-Order Tournaments as Optimum Labor Contracts." Journal of Political Economy 89(5): 841-64.

Markussen, Simen, Knut Roed, Ole J. Rogeberg, and Simen Gaure. 2011. "The Anatomy of Absenteeism." Journal of Health Economics 30(2): 277-92.

Origo, Federica. 2009. "Flexible Pay, Firm Performance and the Role of Unions. New Evidence from Italy." Labour Economics 16(1): 64-78.

Portugal, Pedro, and José Varejao. 2009. Why Do Firms Use Fixed-Term Contracts? IZA Discussion Papers 4380. Bonn, Germany: Institute for the Study of Labor (IZA).

Prendergast, Canice. 1999. "The Provision of Incentives in Firms." Journal of Economic Literature 37(1): $7-63$.

Schmidt, Peter, and Robin Sickles. 1984. "Production Frontiers and Panel Data." Journal of Business and Economic Statistics 2(4): 367-74.

Shapiro, Carl, and Joseph Stiglitz. 1984. "Equilibrium Unemployment as a Worker Discipline Device." American Economic Review 74(3): 33-44.

Siebert, Horst. 1997. "Labor Market Rigidities: At the Root of Unemployment in Europe." The Journal of Economic Perspectives 11(3): 37-54.

Sloof, Randolph, and Mirjam C. van Praag. 2008. "Performance Measurement, Expectancy and Agency Theory: An Experimental Study.” Journal of Economic Behavior and Organization 67: 794-809.

Solow, Robert M. 1979. "Another Possible Source of Wage Stickiness." Journal of Macroeconomics 1(1): 79-82.

Tarantelli, Ezio. 1986. Economia del lavoro. Torino, Italy: Utet.

Van Biesebroeck, Johannes. 2007. "Wage and Productivity Premiums in Sub-Saharan Africa." NBER Working Papers 13306. Cambridge, MA: National Bureau of Economic Research.

Wilson, Nicholas, and Michael J. Peel. 1991. "The Impact on Absenteeism and Quits of Profit-Sharing and Other Forms of Employee Participation.” Industrial and Labor Relations Review 44(3): 454-68.

Winckelmann, Rainer. 1999. "Wages, Firm Size and Absenteeism.” Applied Economics Letters 6: 337-41. 